https://doi.org/10.31713/m1103

\title{
DEVELOPMENT OF ROOF BOLTING TECHNOLOGY FOR APPLICATION IN GAS- AND WATER-BEARING ROCKS \\ Krukovskyi O.P.
}

Institute of Geotechnical Mechanics named by N. Poljakov of National Academy of Sciences of Ukraine, Corresponding member of NAS of Ukraine, Doctor of Technical Sciences, Deputy Director of the Institute, Ukraine

Krukovska V.V.

Institute of Geotechnical Mechanics named by N. Poljakov of National Academy of Sciences of Ukraine, Senior Researcher, Doctor of Technical Sciences, Senior Researcher in Department of Dynamic Effects of Rock Pressure Control, Ukraine

\section{Vynohradov Yu.O.}

Branch for Physics of Mining Processes of the M.S. Poliakov Institute of Geotechnical Mechanics of the National Academy of Sciences of Ukraine, Candidate of Technical Sciences, Junior Researcher in Department of Control of Rocks State, Ukraine

Abstract.

Roof bolting is traditionally used only to ensure the stability of mine workings and it is not considered as a means of influencing filtration processes in the host rocks. The purpose of this work is to substantiate the use of roof bolting as a technological method to reduce gas emission and water inflows into mine workings. To achieve this goal the mathematical model of coupled processes of deformation of layered coal-rock mass around the mine working with roof bolting and fluids filtration in the disturbed area has been developed.

It was shown that roof bolting restrains unloading of the boundary rocks from rock pressure and keeps them in triaxially compressed stress state. The permeability value decreases by the value of its technological component. The influence of roof bolting on the processes of methane and water filtration into the mine working was investigated. Methane filtration rate in the bolted area of the mine roof is equal to zero; consequently, methane from undermined gas emission sources does not participate in the filtration process. In different areas of the intersection of tectonic disturbance, water inflow into the mine working with roof bolting is 3-8 times less than in the working with frames.

Therefore, the use of roof bolting allows not only to keep the mine working in a stable state, but also to significantly reduce fluids inflows. Roof bolting can be 
considered as the second line of defense to be applied in the presence of gas- and water-bearing rocks.

Key words: filtration processes, geomechanical processes, mine workings, numerical simulation, roof bolting technology.

\section{Introduction}

Roof bolting is a spatial system of the roof bolts fixed in boreholes. The most promising method for increasing efficiency of bolts is such their layout in the space, which would keep host rocks in a triaxially compressed state.

Researchers at the Institute of Geotechnical Mechanics analyzed results of long-term observations and laboratory, computational and mine experiments conducted in more than 30 coal mines of Ukraine and established on their basis a concept of the rock-bolt support interaction, according to which supports unite into a single construction that can resist rock pressure. Such supporting limits the destruction of the host rock throughout the whole period of mine working operation. The field of application of roof bolting has been expanded for the difficult mining and geological conditions of coal mines in Ukraine. Thus, the technology of the bearing-bolt supporting was developed [1-3]. Subject to the regulatory requirements, monitoring and operation, the technology of bearing-bolt supporting allows [4]:

- to ensure reliable and safe operation of mine workings throughout the whole period of their operation;

- to increase coal production;

- to increase the average mine working construction speed;

- to simplify the mining work organization schemes;

- significantly improve the working conditions and safety of miners, economic and production performance of coal mines.

Many complications and accidents in mine workings are associated with presence of gas and water in coal beds and sandstones. Mining operations initiate the processes of deformation, cracking, water and gas filtration. Abundant water and methane inflowing in the mine workings, as a rule, leads to accidents, lengthy downtime of longwall faces, reduced productivity and, hence, to economic losses. sed downtime of stopes, reduced productivity and economic losses.

The use of roof bolting allows us to reduce the displacement of rocks into the mine workings to the minimum values, to preserve the 
enclosing rocks in the natural, monolithic state, and, therefore, to prevent the development of cracking in the zone of mine working effect. This suggests that the permeability of the host rocks in this zone will also be preserved at the natural level. This, in turn, should significantly reduce the intensity of fluids filtration and their inflow inside the mine working. The experience of mine shows that technological operations can affect filtration processes in the disturbed zone of the rock mass. Methods of mine workings construction, the amount of stope and wall advance actively influence the dynamics of stress field redistribution [5], the configuration of filtration area, permeability inside it and, consequently, the formation and direction of fluid flows in the disturbed area.

Roof bolting is traditionally used only to ensure the stability of mine workings. It is not considered as a means of influencing filtration processes in the host rocks. The purpose of our work is to substantiate the use of roof bolting as a technological method to reduce gas emission and water inflows into mine workings.

To achieve this goal, we set the following tasks:

- to develop a mathematical model of the coupled processes of deformation of the layered coal-rock mass around the mine working with roof bolting and fluids filtration in the disturbed area;

- to perform its numerical implementation using the finite element method;

- to investigate the influence of roof bolting on the filtration permeability caused by the mine working driving;

- to investigate the influence of roof bolting on the process of methane filtration from gas-bearing rocks and coal into mine workings;

- to investigate the influence of roof bolting on the process of water filtration during the undermining of water-bearing rocks;

- to develop a method to reduce gas emission and water inflows with roof bolting.

\section{Methods}

Deformation of the coal-rock massif can be described by the equation

$$
c_{g} \frac{\partial u_{i}}{\partial t}=\sigma_{i j, j}+X_{i}(t)+P_{i}(t)
$$


where $u_{\mathrm{i}}$ is displacements, $\mathrm{m} ; c_{g}$ is damping ratio, $\mathrm{kg} /\left(\mathrm{m}^{3} \cdot \mathrm{s}\right) ; \sigma_{\mathrm{ij}, \mathrm{j}}$ are derivatives of strain tensor components in $x$ and $y, \mathrm{~Pa} / \mathrm{m} ; t$ is time, $\mathrm{s} ; X_{\mathrm{i}}(t)$ is projections of external forces acting on volume unit of solid body, $\mathrm{N} / \mathrm{m}^{3} ; P_{\mathrm{i}}(t)$ is projections of forces caused by fluid pressure in porous fractured space, $\mathrm{N} / \mathrm{m}^{3}$.

A Coulomb-Mohr criterion is used to describe mathematically a process of rock transition into a disturbed state. A stress-strain state of rocks is analyzed with the help of following geomechanical parameters characterizing a degree of variety of the stress field components $\left(Q^{*}\right)$ and geostatic pressure relief of the rocks $\left(P^{*}\right)$

$$
Q^{*}=\frac{\sigma_{1}-\sigma_{3}}{\gamma H} ; \quad P^{*}=\frac{\sigma_{3}}{\gamma H},
$$

where $\sigma_{1}, \sigma_{3}$ are maximum and minimum components of main stress tensor, $\mathrm{Pa} ; \gamma$ is average weigh of overlying rocks, $\mathrm{N} / \mathrm{m}^{3} ; H$ is mining depth, $\mathrm{m}$.

Deformation of rocks during mining operations leads to a change in their filtration permeability [6-8]. The change in the values of the permeability coefficients depending on the components of the principal stress tensor can be described as follows [8,9]

$$
k_{\mathrm{tech}}=\left\{\begin{array}{l}
0, \text { for } Q^{*}<0.4 \text { and } P^{*}>0.2 \\
k_{\min }, \text { for } 0.4<Q^{*}<0.6 \text { and } P^{*}>0.1 ; \\
\mathrm{e}^{0.26 Q^{*}-4.65}, \text { for } 0.6<Q^{*}<1.0 \text { and } P^{*}>0.1 ; \\
k_{\max }, \text { for } Q^{*}>1.0 \text { or } P^{*}<0.1,
\end{array}\right.
$$

where $k_{\text {tech }}$ is coefficient of permeability, which is formed during the mine working driving, $\mathrm{m}^{2} ; k_{\min }$ is minimal value of permeability coefficient, $\mathrm{m}^{2} ; k_{\max }$ is permeability within zone of fracturing, $\mathrm{m}^{2}$.

It means that $k_{\text {tech }}=0$ within the zone of equal-component compression and elastic deformations, $k_{\text {tech }}=k_{\min }$ within the area of initial fissuring, $k_{\mathrm{tech}}=f\left(\sigma_{i j}\right)$ within the area of intense cracking, and $k_{\mathrm{tech}}=k_{\max }$ in terms of rock fracturing.

Some rock layers are initially permeable and they have permeability $k_{\text {nat }}$. Technological permeability $k_{\text {tech, }}$ which is formed during the mine working driving and depends on the stress tensor components, is superimposed on the natural $k_{\text {nat }}$ permeability fields

$$
K=k_{\text {tech }}+k_{\text {nat }} \text {, }
$$


where $K$ is absolute permeability coefficient, $\mathrm{m}^{2}$.

The equation of plane gas filtration, in terms of the available gasbearing rocks within the filtration area, is as follows [10]

$$
\frac{\partial p}{\partial t}=\frac{K}{2 m \mu_{g}}\left(\frac{\partial^{2} p^{2}}{\partial x^{2}}+\frac{\partial^{2} p^{2}}{\partial y^{2}}\right)+q_{g}(t),
$$

where $p$ is fluid pressure, $\mathrm{Pa} ; m$ is porosity of rock; $\mu_{g}$ is gas viscosity, $\mathrm{Pa} \cdot \mathrm{s} ; x, y$ are coordinates, $\mathrm{m} ; q_{g}(t)$ is function of gas emission, $\mathrm{Pa} / \mathrm{s}$.

The process of water filtration in disturbed rocks is described by the following equation [10]

$$
\frac{\partial p}{\partial t}=\frac{K}{\beta m \mu_{w}}\left(\frac{\partial^{2} p}{\partial x^{2}}+\frac{\partial^{2} p}{\partial y^{2}}\right)+q_{w}(t),
$$

where $p$ is water pressure, $\mathrm{Pa} ; \mu_{w}$ is water viscosity, $\mathrm{Pa} \cdot \mathrm{s} ; \beta$ is water-compressibility factor, $1 / \mathrm{Pa} ; q_{w}(t)$ is water release function, $\mathrm{Pa} / \mathrm{s}$.

The initial and boundary conditions for the tasks set

$$
\begin{aligned}
& \left.\sigma_{y y}\right|_{t=0}=\gamma H ;\left.\quad \sigma_{x x}\right|_{t=0}=\lambda \gamma H ;\left.\quad u_{x}\right|_{\Omega_{1}}=0 ;\left.\quad u_{y}\right|_{\Omega_{2}}=0 ; \\
& \left.u_{x}\right|_{t=0}=0 ;\left.\quad u_{y}\right|_{t=0}=0 ;\left.\quad \quad \quad\right|_{\Omega_{1}}=p_{0} ;\left.\quad p\right|_{\Omega_{2}}=p_{0} ; \\
& \left.p\right|_{t=0}=p_{0} ;\left.\quad \quad p\right|_{\Omega_{3}(t)}=p_{0} ;\left.p\right|_{\Omega_{4}}=0.1 \mathrm{MPa} \text {, }
\end{aligned}
$$

where $\sigma_{x x}, \sigma_{y y}$ are components of stress tensor, $\mathrm{Pa} ; \lambda$ is side thrust coefficient; $u_{x}, u_{y}$ are components of displacement vector, $\mathrm{m} ; p_{0}$ is fluid pressure in undisturbed rocks, $\mathrm{Pa} ; \Omega_{1}$ is vertical outer boundaries; $\Omega_{2}$ is horizontal outer boundaries; $\Omega_{3}(t)$ is time-depending boundary of filtering area; $\Omega_{4}$ is internal contour (mine working).

In order to solve the problems associated with filtration of fluids into a rock bolted working, we applied a finite element method [11, 12]. The roof bolt was simulated by the rod finite elements. At each time iteration [13], the influence of the stress field on the formation of the filtration area, the influence of change in fluid pressure on the stress state and decrease in the strength properties of rocks during soaking (in case of water filtration) are taken into account. 


\section{Results and discussion}

\subsection{Influence of roof bolting on rock permeability}

To form a rock-bolt slab in the mine roof, from 3 to 9 (depending on the size of the cross-section of the mine working and required construction power) steel-polymer bolts $2.4 \mathrm{~m}$ long are used. Deep rope bolts can be used to strengthen the rock-bolt slab.

The number of bolts in the walls of working and the scheme of their installation depend on the height of mine working, the presence of a coal seam, the strength of the coal seam and host rocks. For supporting the rock part of the sides, steel-polymer bolts with a length of 1.5 to $2.4 \mathrm{~m}$ can be used; for supporting the coal seam, plastic and wooden bolts 1.2-1.8 $\mathrm{m}$ long are used.

To study the influence of roof bolting on the permeability of host rock, we considered the cross-section of a mine working in a homogeneous massif consisting of argillite and compared two cases:

- the mine working is supported by frames;

- the mine working is supported with roof bolting.

As a result of the calculation, we have obtained stress fields and zones of inelastic deformations for these two cases. Fig. 1 shows the distributions of $Q^{*}$ parameter values and the zones of inelastic deformations (red color) at the moment of time $t=2$ days.

In the intact massif, outside the zone of influence of the mine working (Fig. 1, white color), rocks are in conditions of triaxial compression. The different-component nature of the stress field here, as a rule, is close to zero $\left(0<Q^{*}<0.2\right)$; fluids are contained in isolated pores, there is no filtration capacity and permeability coefficients is practically zero. With elastic deformation of the rock, microcracks and pores are closed, and filtration properties of the rock change little. The zone where the rock is deformed elastically does not belong to the filtration area either. 
$a$

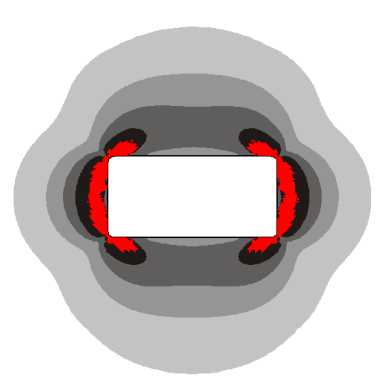

$b$

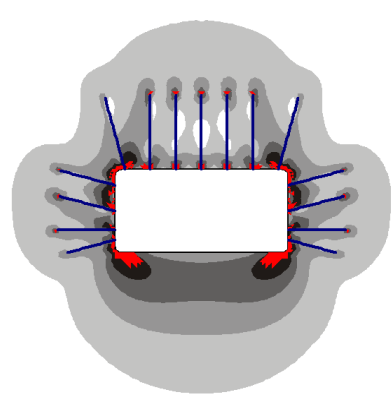

$Q^{*}>0.8$
$0.6<Q^{*}<0.8$
$0.4<Q^{*}<0.6$
$0.2<Q^{*}<0.4$
$Q^{*}<0.2$

Fig. 1. Distributions of $Q^{*}$ parameter values and zones of inelastic deformations: $a$ - the mine working with frames; $b$ the mine working with roof bolting

When constructing the mine working, the stress field around it changes: the minimum components tend to zero, and the maximum ones increase. Beyond the limits of elasticity and up to the ultimate strength, under multi-component loading, the following processes take place: the beginning of cracking $\left(0.4<Q^{*}<0.6\right)$, when the minimum permeability appears, and intense cracking $\left(0.6<Q^{*}<1.0\right)$, when the permeability coefficients increase by 2-3 orders of magnitude in various rocks. Further growth of permeability coefficients beyond ultimate strength occurs only due to the dilatation of existing fractures. In the area of destruction, which is characterized by the condition $P^{*}<0.1$, the permeability coefficients reach its maximum values.

In both cases (Fig. $1 a$ and Fig. $1 b$ ), areas of increased $Q^{*}$ parameter values are formed around the mine workings $\left(Q^{*}>0.4\right)$. The contours of mine workings surround the zones of inelastic deformation, which indicates an increase in the fracturing of the host rock, its stratification and destruction.

However, in the walls and roof of the mine working with roof bolting (Fig. 1b), the zone of inelastic deformations is much smaller than around the mine working with frames (Fig. 1a). In the mine roof, the area of increased $Q^{*}$ parameter values disappears and the undisturbed rock-bolt slab is formed, in which $Q^{*}<0.4$. Roof bolting keeps the boundary rocks in a natural, monolithic state, which ensures the stability of mine working with bolts. 
Using equations (3), we have calculated the values of filtration permeability coefficients in the study area, Fig. 2.

a
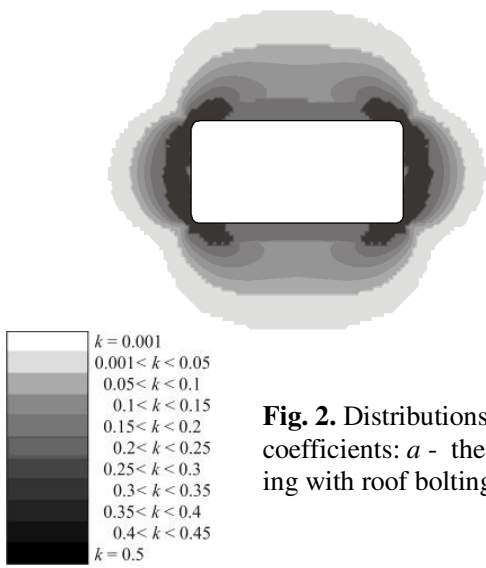
ing with roof bolting $b$

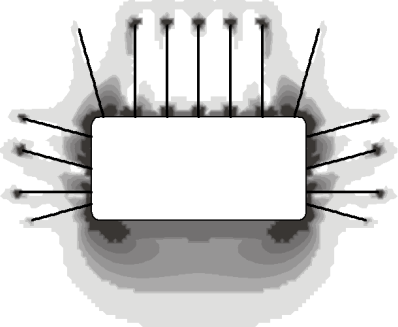

Fig. 2. Distributions of values of filtration permeability coefficients: $a$ - the mine working with frames; $b$ - the mine work-

It can be seen that a filtration area with non-zero permeability coefficients is formed around the working with frames (Fig. 2a). Within this area, fluids can freely move in the direction from the fluids emission source (gas- or water-bearing coal beds and rocks) into the mine working space.

The contours of the filtration area change if bolts are installed in the roof and walls of the mine working, Fig. $2 b$. In this case, the zone impermeable to fluids is formed in the mine roof. The rock from which it is formed, thanks to the bolts system, is preserved in its natural monolithic state. The high degree of integrity can be judged by the well-preserved traces of the executive body of the combine on the surface of the argillite, Fig. 3. Filtration of fluids through such a rock-bolt slab from fluids emission sources located in the mine roof is impossible.

The permeability in the walls of mine working with roof bolts is also significantly lower than in the walls of mine working with frames, Fig. $2 b$. 


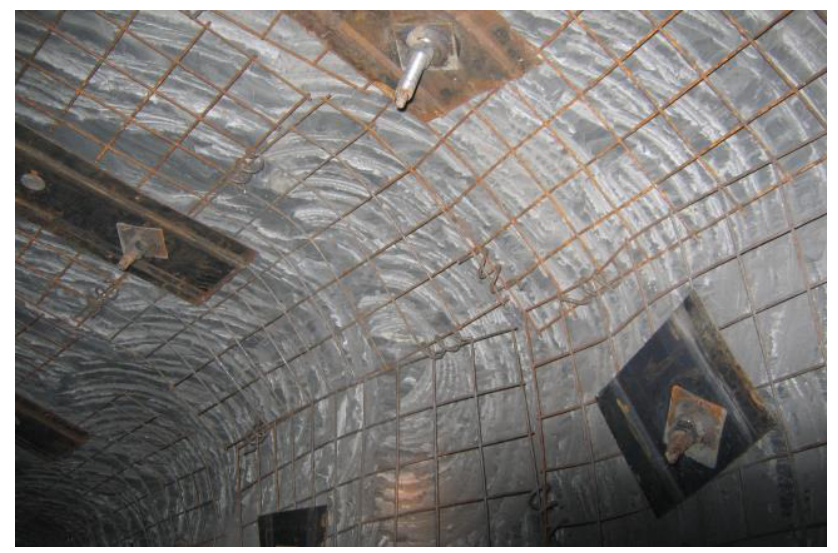

Fig. 3. Surface condition in the mine working with roof bolting

Roof bolting restrains the process of cracking in the zone of working influence. In this case, the size of filtration area is significantly reduced, the permeability inside it decreases, which leads to a decrease in the intensity of filtration movement, to the prevention or reduction of fluids inflow into the mine working with roof bolting.

Through a series of numerical experiments, we have investigated how each individual bolt affects the permeability value. After performing the calculations, we obtained the distributions of $Q^{*}$ parameter values, the zones of inelastic deformations and the fields of permeability coefficients for the cases when 1,3,5,7 and 9 bolts are installed in the mine roof, Fig. 4.

It can be seen that an impermeable region is formed around each bolt, where $k<0.001 \mathrm{mD}$ (shown in white in Fig. 4). When the number of bolts increases, these areas intersect, Fig. $4 d$ and $4 e$, and form an impermeable rock-bolt slab that protects the mine working from fluids inflows from the undermined roof rocks.

When bolts are used, $Q^{*}$ parameter values in the mine roof is reduced. Installation of each additional bolt increases the area of undisturbed rocks where $Q^{*<0.4}$ (Fig. 4) and reduces the size of the zones in which the roof rocks are unloaded from the rock pressure and $P^{*}<0.1$. Thus, the development of the process of cracking in the host rocks is not allowed, their natural solidity is preserved.Calculations showed that each wall bolt WB reduces the area of inelastic deformation zone in the walls of mine working, Fig. 5. 


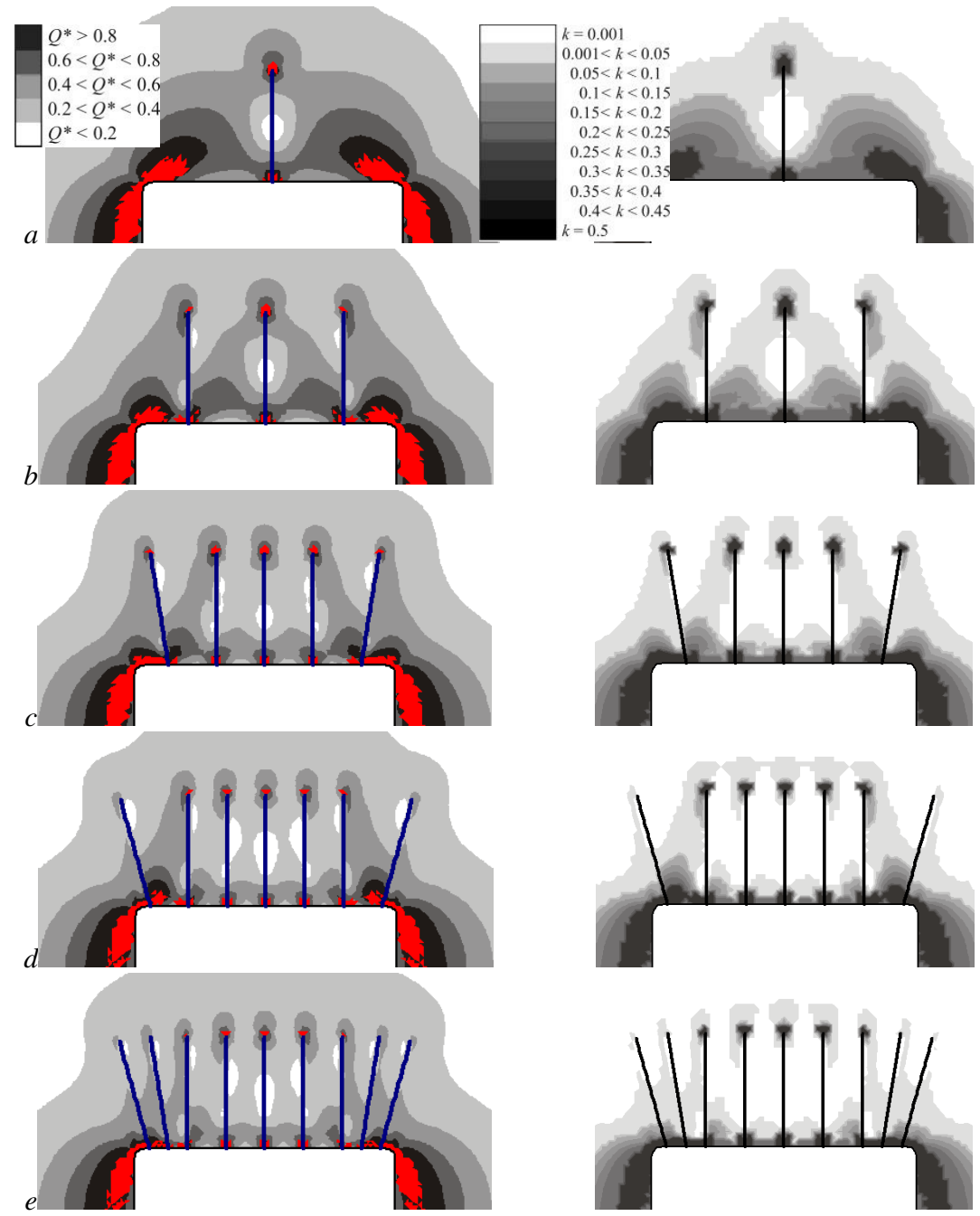

Fig. 4. Distributions of $Q^{*}$ parameter values (left side) and permeability coefficients $k$ (right side) in the mine roof with: $a-1$ roof bolt; $b-3$ bolts; $c$ - 5 bolts; $d-7$ bolts; $e-9$ bolts 


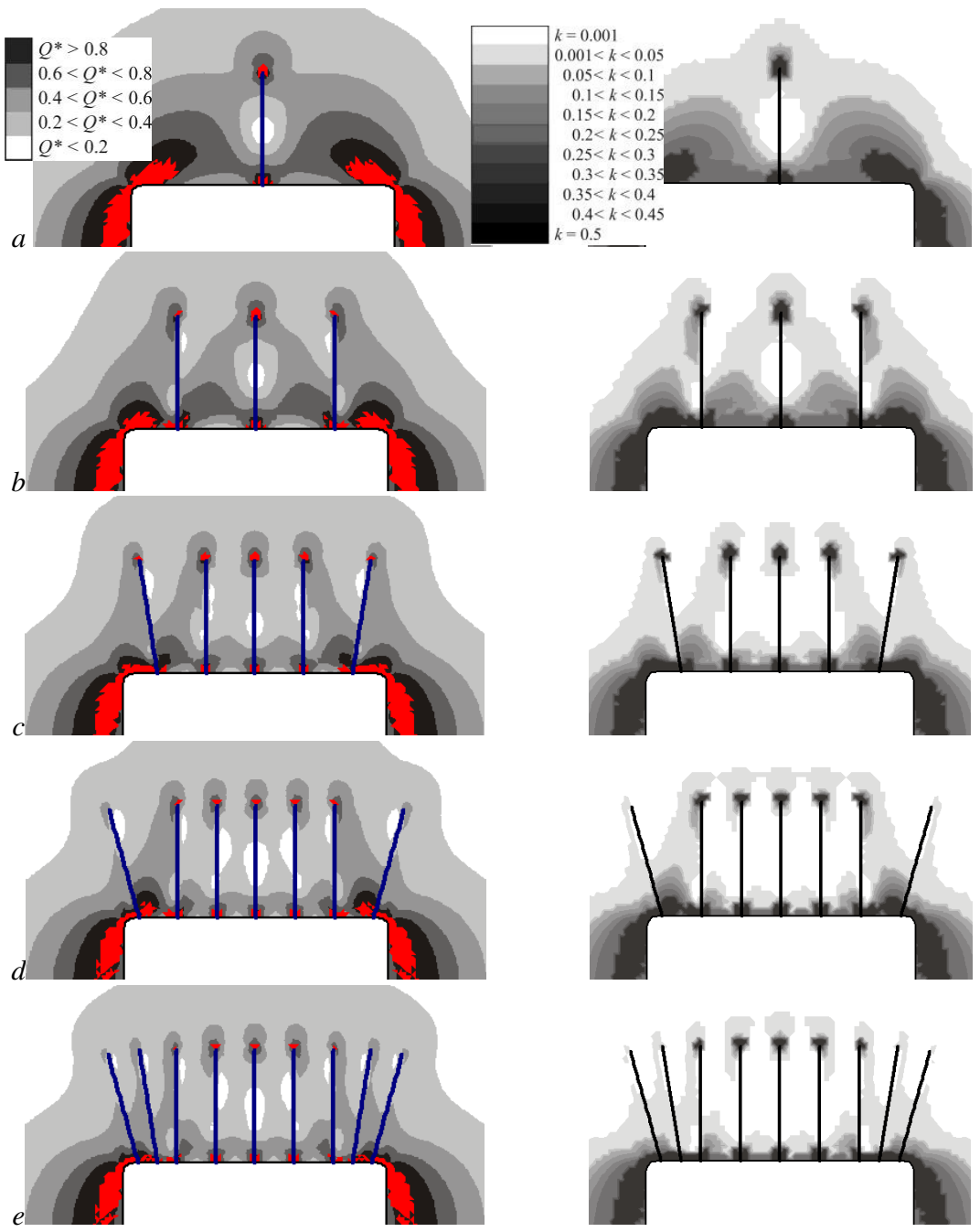

Fig. 5. Distributions of $Q^{*}$ parameter values (left side) and permeability coefficients (right side) in the wall of mine working: $a$ - no bolts; $b$ - with 1 bolt; $c$ - with 2 bolts; $d$ - with 3 bolts; $e$ - with 4 bolts 
The area where $Q^{*}$ parameter values are increased is also reduced. $P^{*}$ parameter values near the contour of mine working increase and become close to 0.2 . This means that the walls of mine working are kept in a stable state, the processes of cracking and coal squeezing are stopped and filtration permeability of this part of the boundary rocks decreases.

The graphs of changes in the values of $k$ in the roof and walls of mine working along the lines $a$ and $b$ (Fig. 6) are shown in Fig. 7.

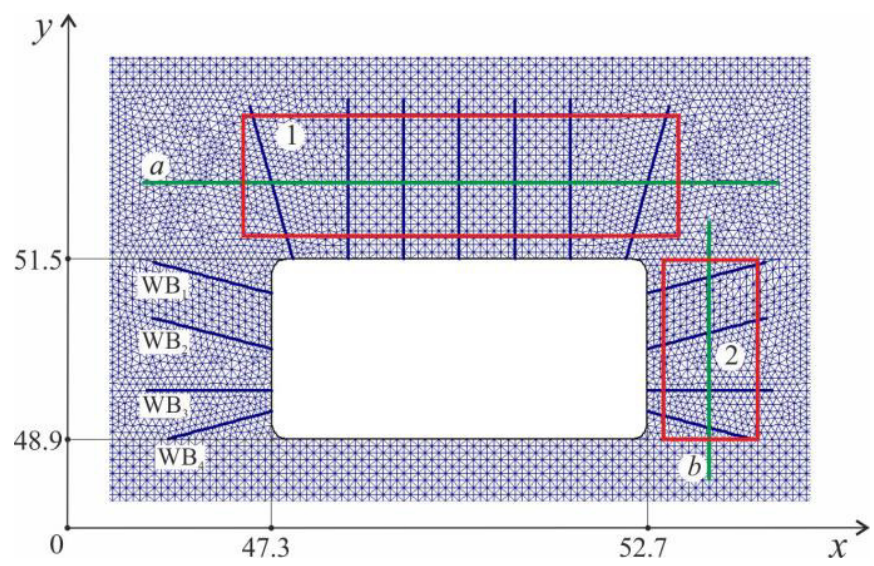

Fig. 6. Central fragment of the finite element mesh: 1 - the bolted area of roof rocks; 2 - the bolted area of wall rocks

Fig. $7 a$ shows if 5 or more bolts are installed in the mine roof, and 4 bolts are installed in the each wall of the mine working, then the permeability coefficients of the host rocks do not exceed $0.001 \mathrm{mDa}$ (for the above-described initial, boundary, mining and geological conditions and bolts location scheme).

The performed calculations show that wall bolts reduce filtration permeability coefficients in the walls of mine working to a level of $0.001 \mathrm{mDa}$ and below:

- bolt $\mathrm{WB}_{1}$ by $35 \%$;

- bolts $\mathrm{WB}_{1}$ and $\mathrm{WB}_{2}$ by $46 \%$;

- $\mathrm{WB}_{1}, \mathrm{WB}_{2}$ and $\mathrm{WB}_{3}$ by $77 \%$;

- $\mathrm{WB}_{1}, \mathrm{WB}_{2}, \mathrm{WB}_{3}$ and $\mathrm{WB}_{4}$ by $100 \%$. 

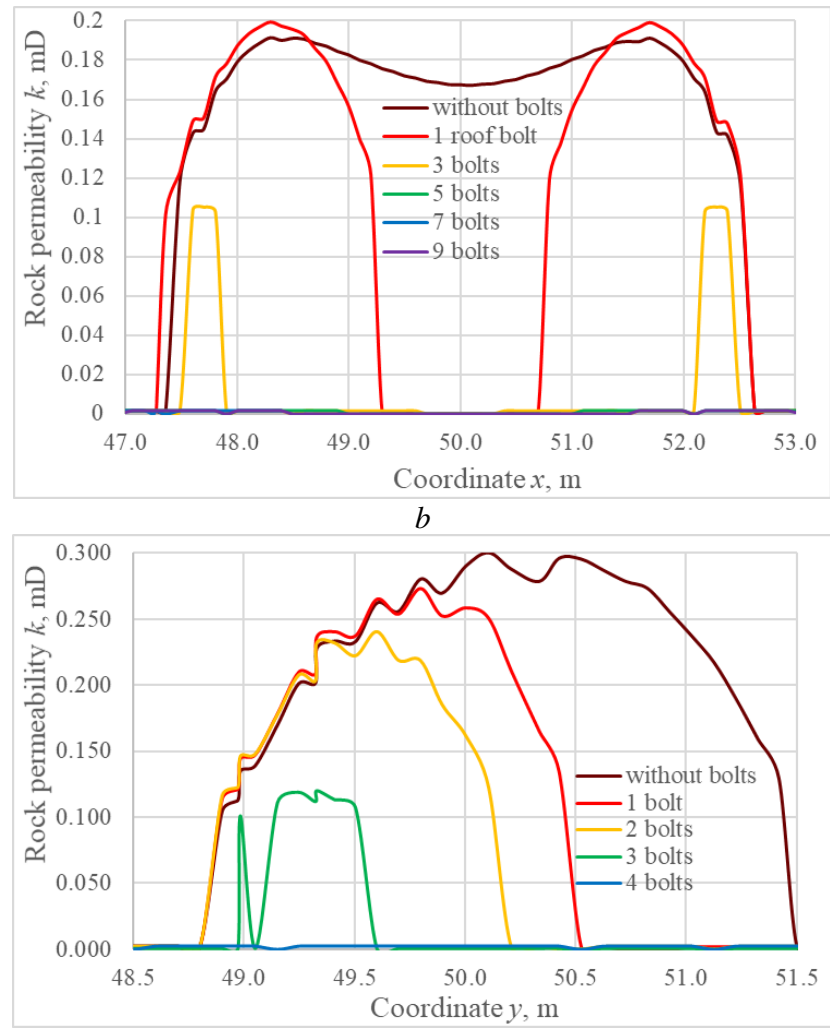

Fig. 7. Rock permeability: $a$ - in the mine roof; $b$ - in the walls of mine working

The change in the average permeability coefficients value in the bolted areas (Fig. 6) of the mine roof and walls is shown in Fig. 8.

Each bolt installed in the roof of mine working (if their number is less than 7) reduces the average permeability of the roof rocks by 10$40 \%$. However, a further increase in the number of bolts does not lead to any significant change in the average permeability in the bolted area of the mine roof.

Each of the bolts installed in the wall of the mine working reduces the average value of the permeability coefficients in the bolted area by $8-38 \%$. 


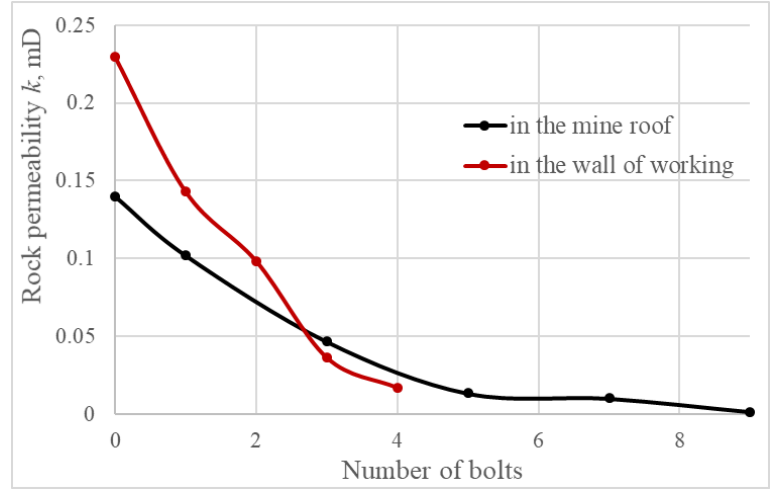

Fig. 8. Average rock permeability in the mine roof and walls

Roof bolting reduces the average filtration permeability caused by the redistribution of the stress field during excavation by 15 times or more, Fig. 8.

\subsection{Methane filtration into mine workings with roof bolting}

Mining operations in coal mines initiate the processes of rock deformation and filtration of methane, which is contained in the fractured-pore space of coal and gas-bearing sandstones. Increased methane inflow from the coal bed and undermined rocks, methane breakthroughs and blowers, gas-dynamic phenomena are the result of two closely coupled processes occurring together in time: stress redistribution and gas filtration.

In many cases, methane released into the atmosphere of mine workings impedes efficient coal production and becomes a threat to the safety of miners. On the other hand, coal bed methane is a quality gas that requires minimal processing. It is environmentally friendly and efficient fuel than coal. Methane can be extracted as an independent fossil and as a by-product obtained in the process of degassing. In both cases, the study of the methane filtration process is of scientific and practical interest.

Using the above mathematical model of the coupled processes of changing the stress state of the gas-bearing rocks and methane filtration, we investigated how the roof bolting affects filtration parameters. As an example, the conditions for Western flank ventilation en- 
try №23, coal seam $i_{3}$ of the Sukhodolskaya-Vostochnaya mine of Krasnodonugol PJSC were considered.

This rectangular mine working was constructed at a depth of $915 \mathrm{~m}$ by drilling-and-blasting way along a gas-bearing coal seam with a thickness of $1.9 \mathrm{~m}$ and a strength of $15 \mathrm{MPa}$. The seam roof is mainly represented by siltstone with a thickness of $3.0 \mathrm{~m}$, which is unstable in its lower part. This can provoke collapses to a height of $1.0 \mathrm{~m}$. Further, a gas-bearing sandstone with a thickness of $10 \mathrm{~m}$ occurs in the seam roof. The gas content of coal is $22.5 \mathrm{~m}^{3} / \mathrm{t}$, the gas content of sandstone is $1.5 \mathrm{~m}^{3} / \mathrm{t}$.

The bolts location scheme for Western flank ventilation entry №23 is shown in Fig. 9.

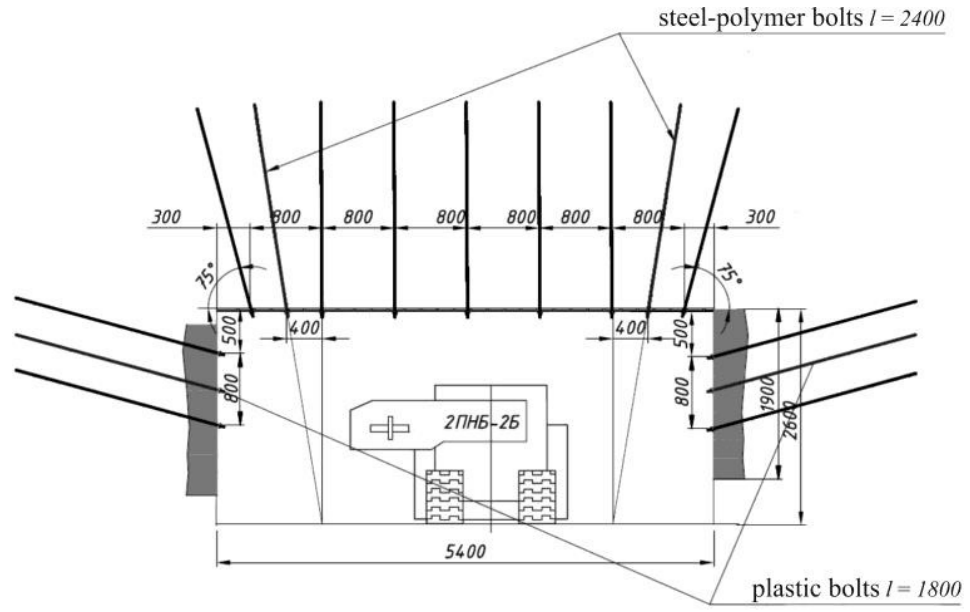

Fig. 9. The bolts location scheme

Fig. 10 shows distributions of $Q^{*}$ parameter values and the areas of inelastic deformations calculated for the mining and geological conditions of Western flank ventilation entry No.23. For comparison, the calculation results are presented in the cases of using frame support and roof bolting according to the scheme shown in Fig. 9.

Over time, in the host rocks, $Q^{*}$ parameter values increase and the zone of inelastic deformations grows. It can be seen that the presence of more durable sandstone in the mine roof leaves an imprint on distribution of $Q^{*}$ parameter values. 


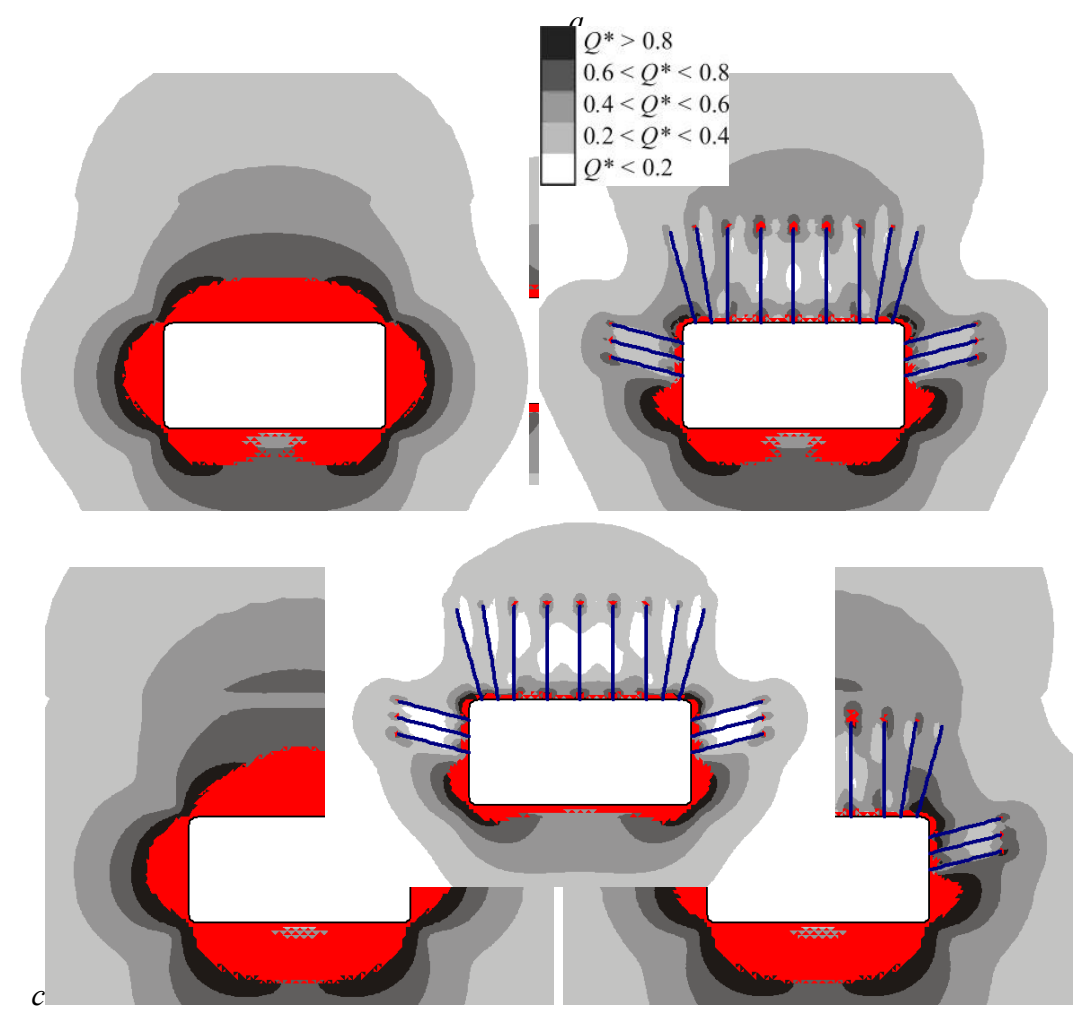

Fig. 10. Distributions of $Q^{*}$ parameter values around the mine working with frames (left side) and roof bolting (right side): $a-t=$ day; $b-t=3$ days; $c-t=15$ days

A rock-bolt slab is formed in the mine roof with bolts, the siltstone in this area is preserved in its natural, monolithic state and $Q^{*}<0.4$. In the bolted areas of the roof and walls of the mine working, the zone of inelastic deformations practically disappears; with the installation of bolts, the process of cracking in the mine roof mine does not develop, Fig. 10.

Based on the results of calculating geomechanical parameters, the field of permeability coefficients was calculated, Fig. 11. 


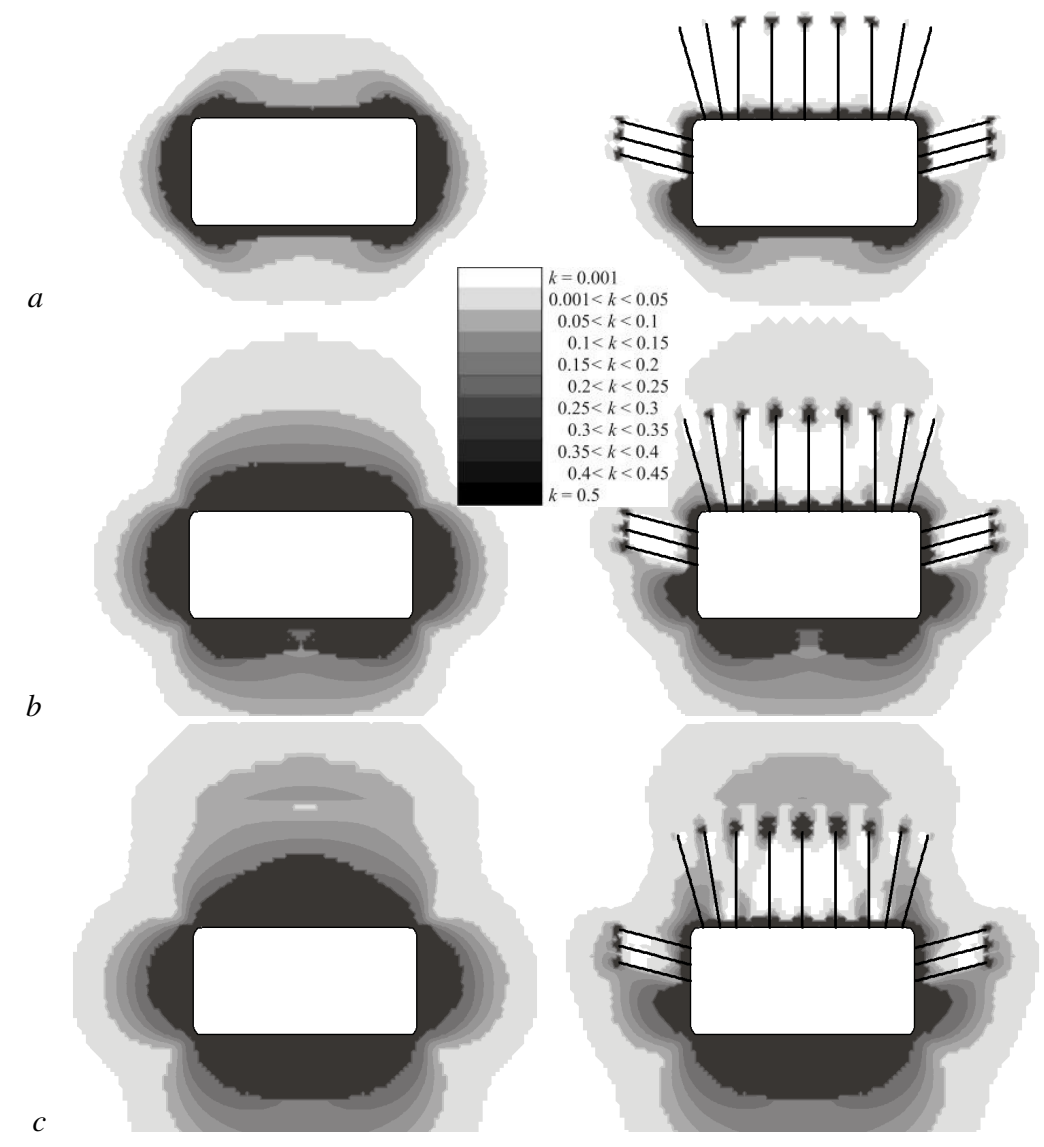

Fig. 11. Distributions of permeability coefficients values around the mine working with frames (left side) and roof bolting (right side): $a-t=1$ day; $b-t=3$ days; $c$ $t=15$ days

In the case of frame support, the filtration area, where $k>0$, includes the coal seam in the walls of mine working and the lower part of the gas-bearing sandstone located in the roof. Inside this filtration area, methane can freely move in the direction from the gas emission sources into the mine working atmosphere, the pressure of which $(0.1 \mathrm{MPa})$ is much lower than the methane pressure in the undisturbed massif (up to 8-12 MPa). 
On the left side of Fig. 11, you can see how the contours of filtration area change if the mine working is supported with roof bolts. In this case, both in the coal seam, in the walls of mine working, and in its roof, between the sandstone and the mine working, there are areas impermeable to gas. The bolts keep the siltstone in these areas in its natural monolithic state. Methane filtration through such an area is impossible.

Fig. 12 shows the isobars of relative methane pressure $p / p_{0}\left(p_{0}\right.$ is methane pressure in the undisturbed massif) in the host rocks around the mine workings with frames and roof bolting.

Over time, methane pressure drops in those parts of the coal seam that are adjacent to the mine working with frame support, Fig. 12, on the left side. This indicates that the coal seam is degassed; methane moves from it into the mine atmosphere. After 2 weeks, the area of low methane pressure captures the lower part of the gas-bearing sandstone, Fig. $12 c$, on the left side. Around the mine working with bearer frame support, the process of methane filtration is actively taking place.

In Fig. 12c, on the right side, you can see that the low pressure area does not reach the gas-bearing sandstone as a result of formation of the impermeable rock-bolt slab in the mine roof. That is, methane from this gas emission source does not enter the mine working with roof bolting, which will significantly reduce methane content in its atmosphere. Due to the influence of the wall bolts, the volume of the degassed part of the coal seam also decreases.

The graphs of the change in time of the relative gas pressure along the vertical line passing through the center of mine working and along the horizontal line passing through the center of coal seam are shown in Figures 13 and 14. Coordinate $y=51.5 \mathrm{~m}$ is the roof of mine working; coordinate $y=54.5 \mathrm{~m}$ is the lower boundary of sandstone; coordinate $x=52.7 \mathrm{~m}$ is the right wall of mine working. 


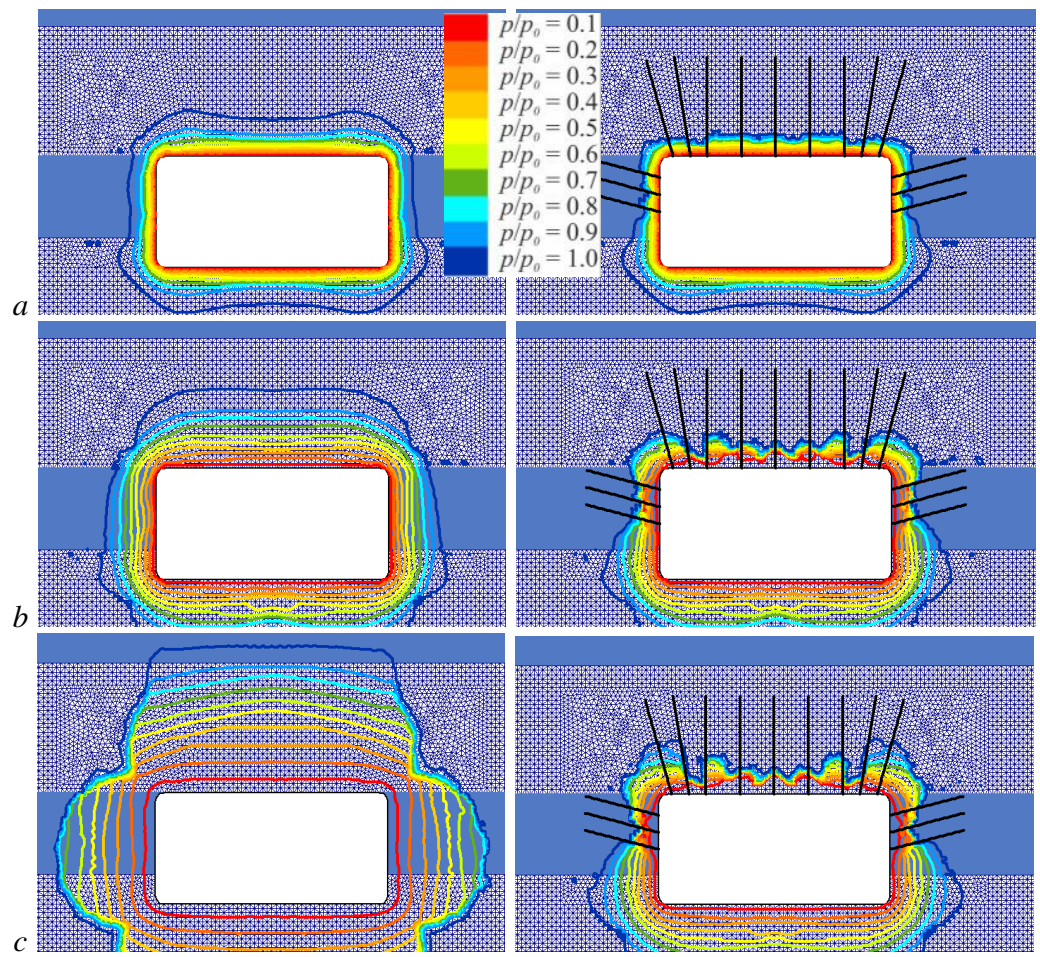

Fig. 12. Isobars of relative methane pressure around the mine working with frames (left side) and roof bolting (right side): a - $t=1$ day; $b-t=3$ days; $c-t=15$ days
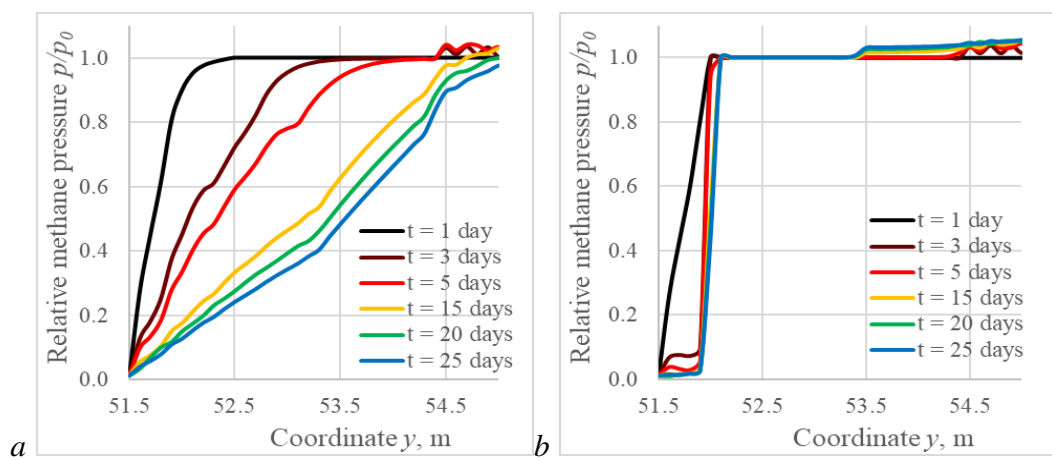

Fig. 13. Relative methane pressure in the mine roof: $a$ - mine working with frames; $b$ - with roof bolting 
In the mine roof with frame support, methane pressure gradually decreases over time. After 15 days, methane pressure begins to decrease in the lower part of the gas-bearing sandstone, Fig. 13a. In the mine roof with roof bolting, the area of low methane pressure does not extend into the depth of massif for more than $0.5 \mathrm{~m}$, Fig. 13a,b
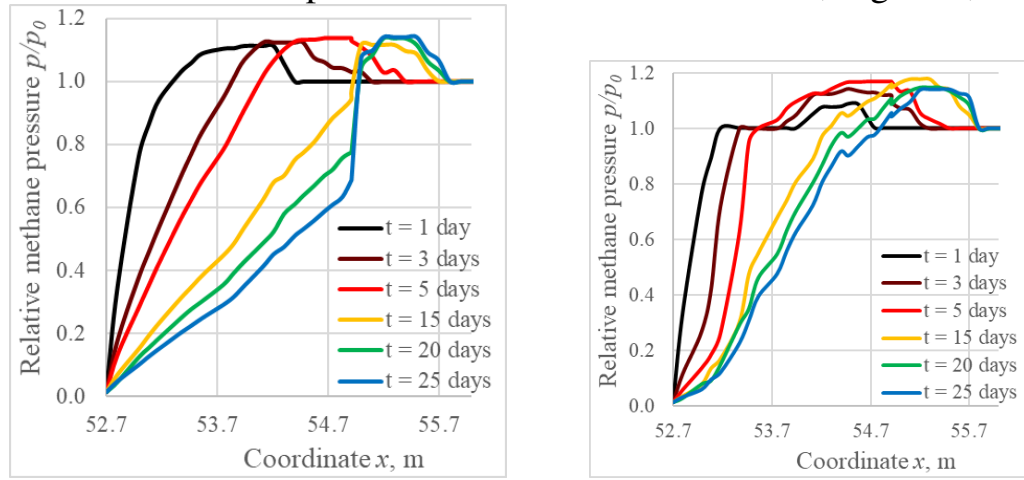

Fig. 14. Relative methane pressure in the wall of mine working: $a$-with frames; $b$ - with bolts

As you can see in Fig. 14, in the walls of the mine, in the area of bearing pressure, methane pressure in the coal seam exceeds initial seam pressure. The effect of increasing seam pressure in the bearing pressure zone is mentioned in [14-16]. This occurs as a result of mechanical compression of rocks and a reduction in the volume of fractured-pore space. You can see also that the pressure drop in the coal seam occurs more slowly if the walls of the mine working are bolted.

The methane filtration rate in the bolted area of the mine roof (Fig. 15b) for $1.5 \mathrm{~m}$ is equal to zero, which confirms the absence of gas filtration through the rock-bolt slab. In the walls of mine working (Fig. 16b), the modulus of filtration rate in the bolted area is reduced by an average of 9 times in comparison with the mine working, which is supported by frames.

At the same mine (Sukhodolskaya-Vostochnaya mine), the Group ventilation entry in block No.1 was constructed along a coal seam with a thickness of $1.8 \mathrm{~m}$ and a natural gas content of $22.5 \mathrm{~m}^{3} / \mathrm{t}$. Sandstone with a thickness of $20-30 \mathrm{~m}$ and a natural gas content of $1.5 \mathrm{~m}^{3} / \mathrm{t}$ lies in the mine roof, which is supported with bolts. The $12^{\text {th }}$ eastern conveyor drift was constructed nearby, in the same mining and geological conditions, using frame support. According to the 
ventilation and safety service, whose task is to control underground air, the methane content of the Group ventilation entry during the construction time and before the approach of the longwall was significantly less than that of the $12^{\text {th }}$ eastern conveyor drift.

a

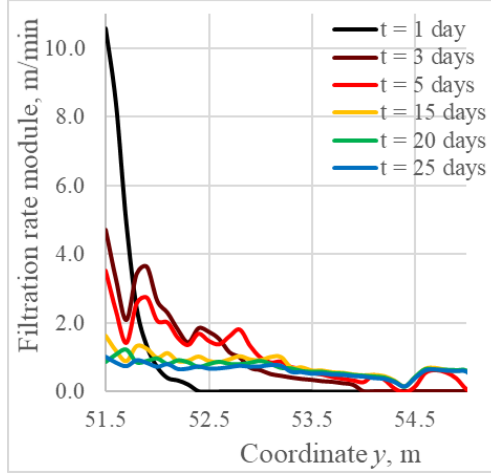

b

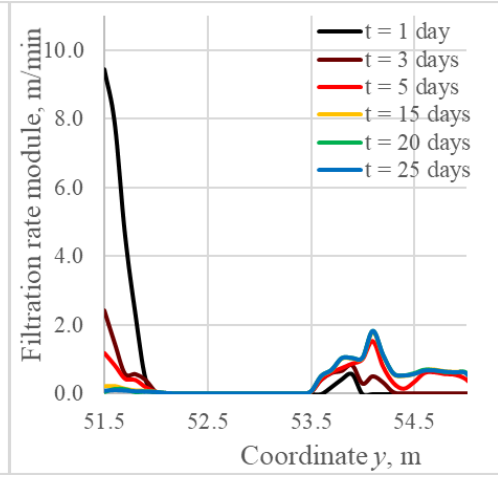

Fig. 15. Module of methane filtration rate in the mine roof: $a$ - mine working with frames; $b$ - mine working with roof bolting
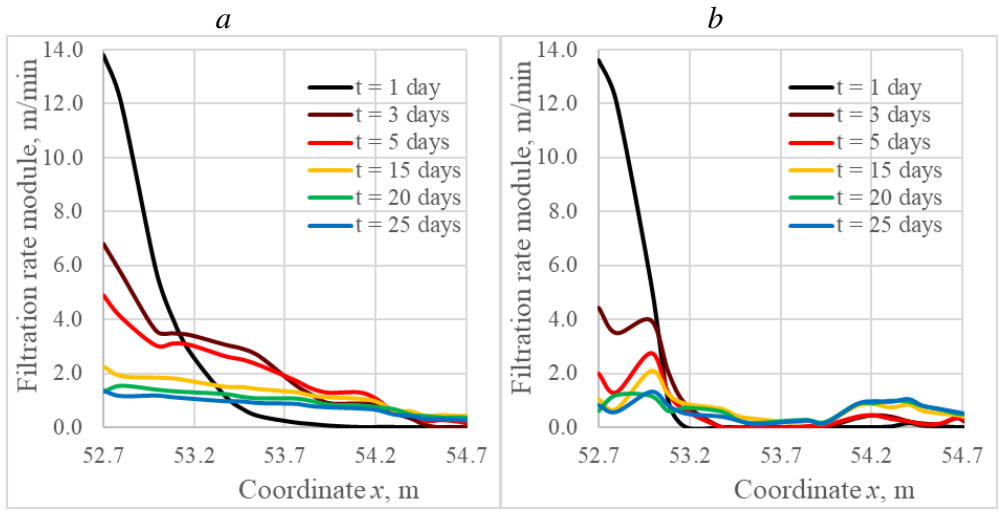

Fig. 16. Module of methane filtration rate in the wall of mine working: $a$ - with frames; $b$ - with bolts

Similarly, at the Samsonovskaya-Zapadnaya mine, PJSC Krasnodonugol, in the same mining and geological conditions, Ventilation drift of the 8th eastern inclined longwall, which was supported with bolts, and the 8th eastern conveyor slope, which was supported 
with frames, were constructed along the coal seam $k_{2}^{b}$. At the seam $k_{2}^{b}$ roof there is coal seam $k_{2}^{t}$ with a thickness of $0.2-0.35 \mathrm{~m}$ and sandstone with a thickness of 32.6-38.9 m. Natural gas content of coal seams is $20-25 \mathrm{~m}^{3} / \mathrm{t}$; natural gas content of sandstone is $5 \mathrm{~m}^{3} / \mathrm{t}$. According to the ventilation and safety service, the methane content of Ventilation drift, which was supported with bolts, was significantly less than the methane content of the $8^{\text {th }}$ eastern conveyor slope.

Such results show that roof bolting can be used as a technological method of reducing methane content in mine workings [17].

\subsection{Water filtration into mine workings with roof bolting}

Ukrainian coal mines are notable for complicated geological conditions due to the great number of tectonic disturbances and flooded rocks. Different forms of geological structures, both plicate and disjunctive, characterize Donbas. Most of the Donbas coal mines are concentrated in large synclinal folds [18]. There is a failure of rocks integrity and an increase in their permeability in zones of local folding [19]. Permeability of rocks reaches its maximum in areas with the highest concentration of tectonic stresses [20]. Type and forming conditions of the faults determine their influence on the filtration properties of rocks. If joint fissures are formed under conditions of stretching of the earth's crust (mainly faults), then they increase permeability of the coal-bearing deposits in the zone adjacent to the fault [21].

The hydrogeological structure of the Western Donbas is a system of aquifers and complexes that cover the entire sedimentary layer and the upper part of the fractured zone of crystalline rocks. The total thickness of the flooded rocks ranges from $20 \mathrm{~m}$ to $1660 \mathrm{~m}$ and more, and it increases in the direction of rocks deepening to the axis of the Dnipro-Donetsk trough [22]. Water inflow into the mine workings mainly depends on the features of the geological structure of the mine fields and particularly on the tectonic disturbance of rocks, the number of aquifers, their thickness, pressure and filtration permeability [22-24]. For example, water production in the N.I. Stashkov Mine (the most water-flooded one in the Western Donbas) is $1640 \mathrm{~m}^{3} / \mathrm{h}$. When the edge rocks are flooded, they become soaked and their strength decreases. This leads to a loss of workings stability and re- 
quires additional finance for water extraction and supporting of mine workings $[25,26]$.

We considered a possibility to use roof bolting in the mine workings in order to reduce water inflows from the undermined waterbearing rocks in the most difficult hydrogeological conditions when crossing tectonic faults.

The coal and rocks are ground and have an initial tectonic permeability on 10-20 m from both sides of the fault. Some rock layers are also initially permeable and they have permeability $k_{\text {nat }}$. Technological permeability $k_{\text {tech, }}$ which is formed during the mine working driving and depends on the stress tensor components, is superimposed on the tectonic $k_{\text {tect }}$ and natural $k_{\text {nat }}$ permeability fields. Formula (4) in this case can be written in the form

$$
K=k_{\text {tech }}+k_{\text {tect }}+k_{\text {nat }} .
$$

As an example, we considered a longitudinal section of a permanent working of $4 \mathrm{~m}$ high, which is constructed at complicated conditions, similar to the conditions of the eastern main entry of the N.I. Stashkov Mine. There is a watered fractured coal bed with a thickness of $0.4 \mathrm{~m}$ and watered sandstone with a thickness of $2.2 \mathrm{~m}$ in the mine roof. There is watered sandstone with a thickness of $0.8 \mathrm{~m}$ in the mine face. The permanent working intersects a disjunctive tectonic fault with displacement amplitude of $1 \mathrm{~m}$.

The central fragment of the finite element mesh for this problem is shown in Fig. 17.

We assumed that initial permeability of the watered sandstones is $0.002 \mathrm{mDa}$, initial permeability of the watered coal bed is $0.005 \mathrm{mDa}$; permeability in the area $l_{1}=3 \mathrm{~m}$ from displacement plane is $0.5 \mathrm{mDa}$; in the area $l_{2}=7 \mathrm{~m}$ is $0.1 \mathrm{mDa} ; p_{0}=3.5 \mathrm{MPa}$. We considered the cases when permanent working is supported by the frame support and roof bolting and its face is located at different distance $L$ (Fig. 17) from the tectonic fault:

a - $L=12 \mathrm{~m}, L>l_{1}+l_{2}$, the permanent working is outside the influence of tectonic fault;

$b-L=7 \mathrm{~m}, l_{1}<L<l_{1}+l_{2}$, the permanent working is in the slightly disturbed area;

$c-L=1 \mathrm{~m}, L<l_{1}$, the permanent working is located in the most disturbed zone of tectonic fault. 


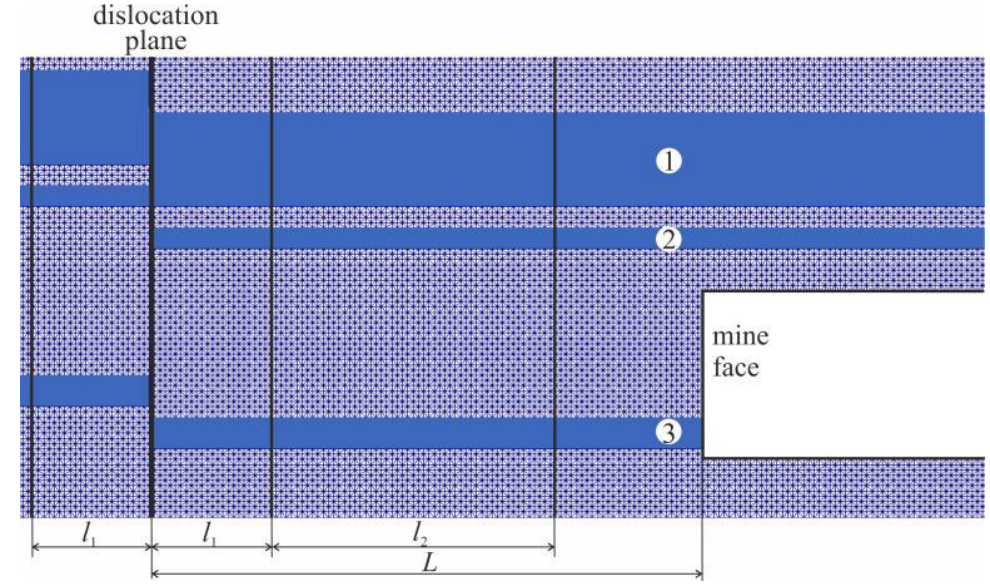

Fig. 17. The central fragment of the finite element mesh: 1,3 - watered sandstones; 2 - watered fractured coal bed

As a result of modeling, the fields of stresses and zones of inelastic deformations were obtained, Fig. 18.
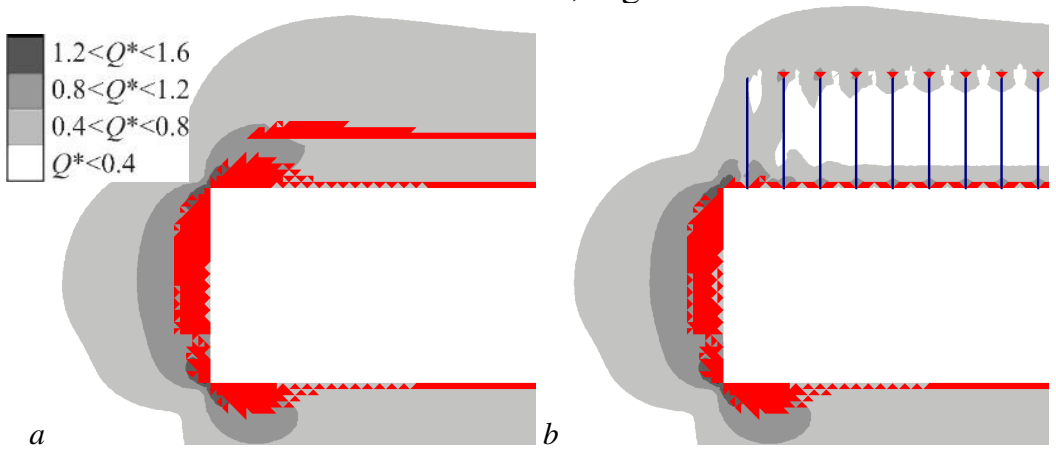

Fig. 18. Distribution of $Q^{*}$ parameter values and inelastic deformation zones: $a-$ the permanent working with frames; $b$ - the permanent working with roof bolting

Hereinafter, the calculation results are given for $t=1$ day after the mine face movement.

The Fig. 18 shows that area of increased diversity of the stress field components is formed around the mine working. Single defects, not interacting between each other, are accumulated in zone where $0.4<Q^{*}<0.8$. In areas where $0.8<Q^{*}<1.2$, the process of intense cracking develops. Here, uncontrolled growth of cracks takes place, 
and deformations rapidly increase due to the propagation of cracks and loosening of the rock [27]. Zone of inelastic deformation (is shown in red) surrounds the permanent working contour, hence, indicating the destruction of rocks.

In the mine roof with frame support (Fig. 18a), the disturbed zone includes both coal bed and sandstone. Here, weak coal bed is completely destroyed.

When using roof bolting (Fig. 18b), zone of inelastic deformations is significantly reduced in boundary rocks of the roof and completely disappears in the coal bed. In the bolted area, rocks and bolts form a slab, where $Q^{*}<0.4$. Here, both the rocks and the weak coal bed are in a triaxially compressed state that keeps them from destruction.

The results of the permeability coefficient calculation are shown in Fig. 19. In these figures, we can see dark zones of tectonic permeability and lighter zones of natural permeability in water-flooded sandstones and coal bed.

A filtration area up to $2.4 \mathrm{~m}$ deep is formed in the mine roof with frame support (left side of Fig. 19) to where the watered coal bed enters completely and sandstone enters partially. Inside this filtration area, water can move towards the contour of the mine. When the working face approaches the disjunctive disturbance, Fig. 19b and $19 c$, it moves into the zone of disturbed rocks, which stratify easily and are destructed during undermining. The bearer support is not able to suppress this process, and filtration permeability is significantly increases in this zone.

Contours of the filtration area are changed when bolts are installed in the mine roof (right side of Fig. 19). The use of roof bolting restrains the unloading of the boundary rocks from the rock pressure and keeps them in a triaxially compressed stress state. Therefore, in all cases of the mine face location relative to the tectonic fault plane, the resulting permeability $K$ decreases by the value of its technological component.

Outside of the influence of the tectonic fault (right side of Fig. $19 a$ ), depth of permeable zone in the mine roof is reduced by 7-8 times in comparison with the same zone in the left side of Fig. 19a. The impermeable rock-bolt slab is preserved between the watered 
layers and the roof of the permanent working. As a result, the process of water filtration from aquifers into the mine working is inhibited.
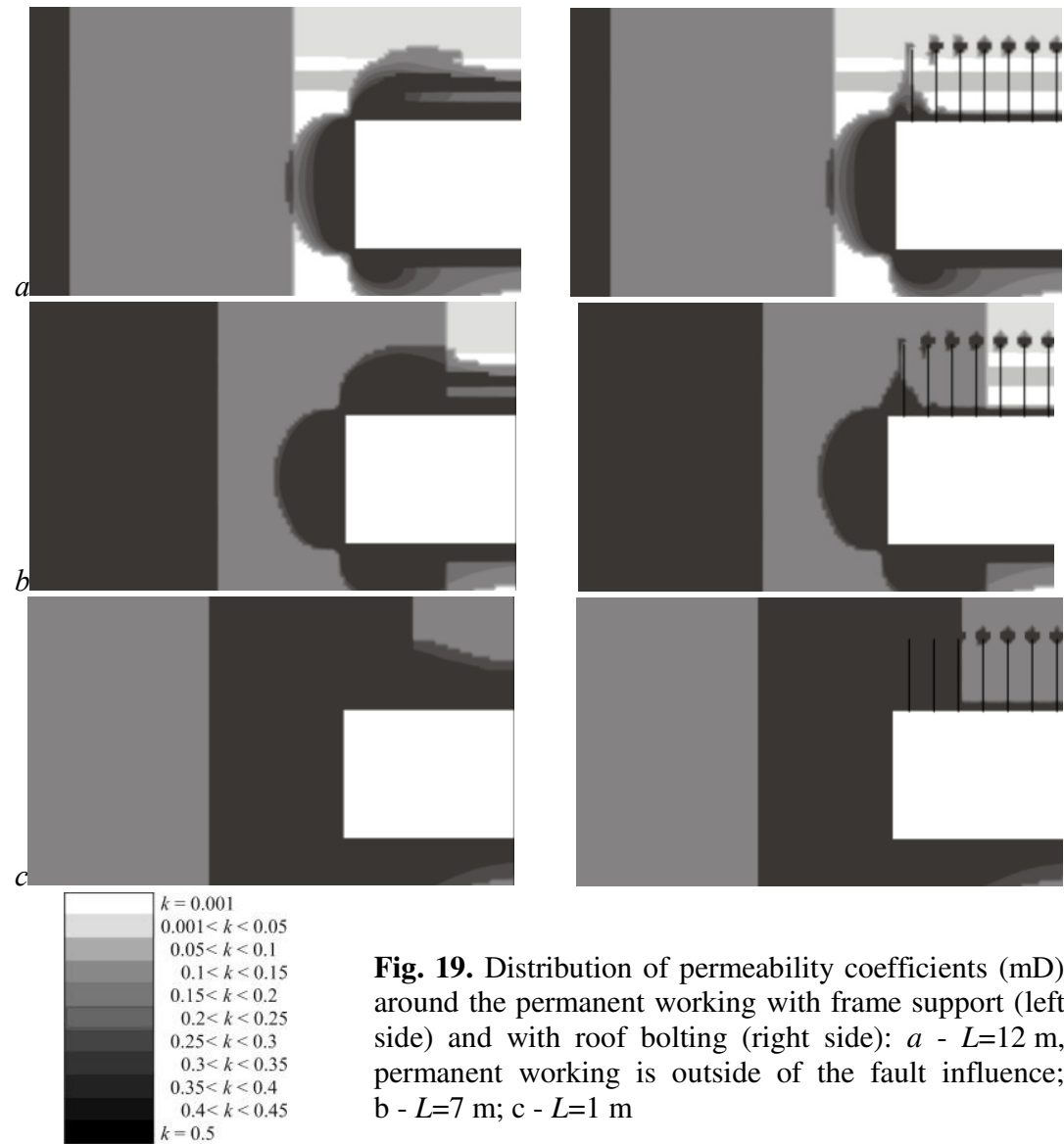

Fig. 19. Distribution of permeability coefficients $(\mathrm{mD})$ around the permanent working with frame support (left side) and with roof bolting (right side): $a-L=12 \mathrm{~m}$, permanent working is outside of the fault influence; b - $L=7 \mathrm{~m}$; c $-L=1 \mathrm{~m}$

In disturbed zone near the fault, action of the steel-polymer bolts only is not sufficient to form an impermeable slab. For this purpose, injection bolts, for example, could be used here. However, in the roof of permanent working with roof bolting (right sides of Fig. $19 b$ and $19 c)$, the permeability is significantly lower than in zone with the frame support (left sides of Fig. $19 b$ and 19c), which should reduce water inflow into the mine working in the hazardous zone.

The distribution of water pressure values are shown in Fig. 20. It can be seen that water pressure in the watered beds near the fault is 
significantly reduced as compared with formation pressure, Fig. $20 b$. As practical experience shows, the increased permeability of rocks in zones of tectonic faults causes the movement of deep pressured water along the plane of displacement in the vertical direction.
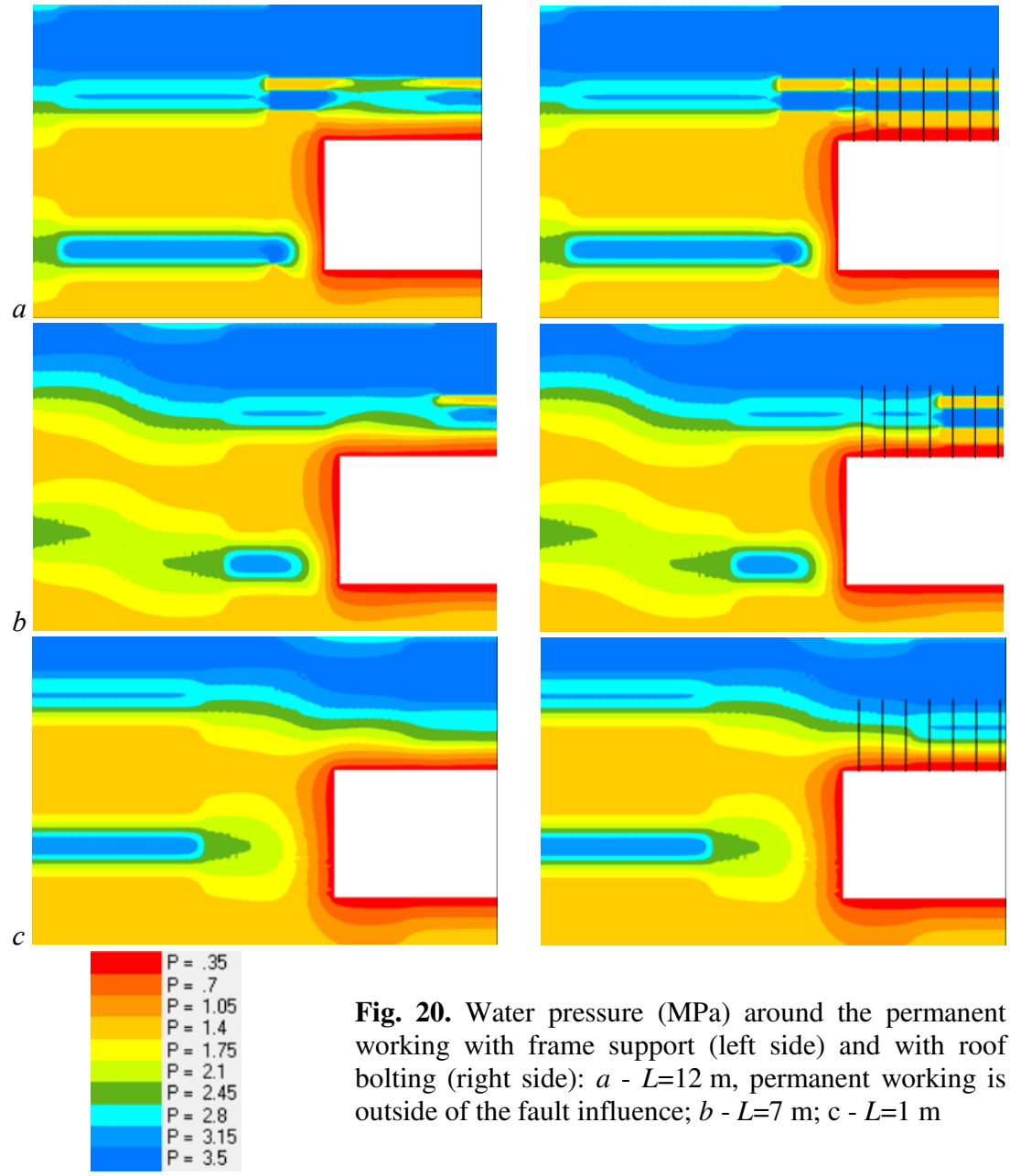

Fig. 20. Water pressure (MPa) around the permanent working with frame support (left side) and with roof bolting (right side): $a-L=12 \mathrm{~m}$, permanent working is outside of the fault influence; $b-L=7 \mathrm{~m}$; c - $L=1 \mathrm{~m}$

In the mine roof with frame support, the process of water filtration is actively taking place both outside the disturbed zone and near the tectonic fault. Water pressure in the undermined watered coal bed and in part of sandstone decreases (left side of Fig. 20). Water moves 
from areas with higher pressure to the mine working where the pressure is minimal. When the mine face approaches the fault and enters the disturbed zone, the intensity of the filtration process increases (left sides of Fig. $20 b$ and 20c). The water inflow into the permanent working from the roof is doubled, and from the watered sandstone in the mine face increases by 1.5 times, Fig. 21.

$a$

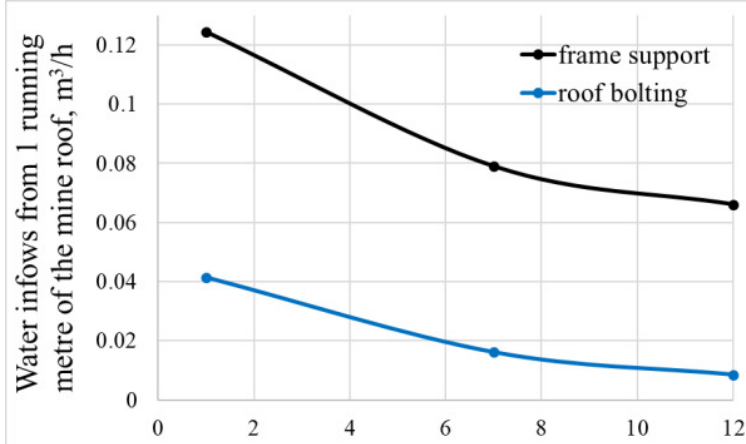

Distance from the fault to the mine face, $L, \mathrm{~m}$

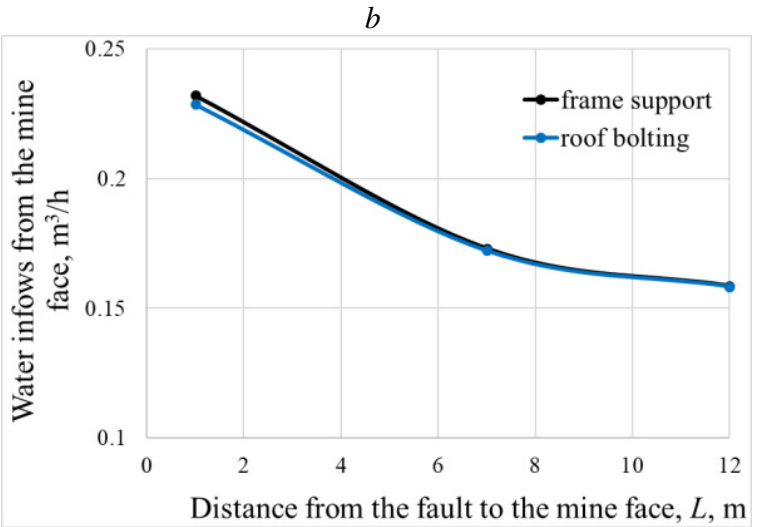

Fig. 21. Water inflow: $a$ - from undermined roof rocks (per 1 running meter of the permanent working); $b$ - from the mine face

If the roof bolting is used, the coal bed pressure and sandstone pressure practically do not change in the mine roof, in the area outside the zone of influence of tectonic disturbance (right side of Fig. 20a). This indicates a significant decrease in the intensity of the fil- 
tration process. The water inflow from the roof into the bolted mine working is almost 8 times less than into the mine working with frame supports, Fig. 21a. We can assert that outside the zone of fault influence, the impermeable rock-bolt slab in the roof reduces water inflow into the mine working to a minimum. When the mine face approaches the tectonic fault, where the roof rocks have already been disturbed as a result of tectonic impact, the roof bolts can only reduce the value of the filtration permeability by the value of $k_{\text {tech }}$. However, this is sufficient to reduce the water inflow by 5 times at $L=7 \mathrm{~m}$ and by 3 times at $L=1 \mathrm{~m}$, Fig. $21 a$.

The water flow rate from the watered sandstone in the mine working face increases by 1.5 times when it approaches the fault and does not depend on the kind of roof supporting, Fig. $21 b$.

Roof bolting in mine workings at difficult hydrogeological conditions, when they cross tectonic faults, allows to reduce permeability of tectonically disturbed host rocks, slow down the water filtration process and reduce water inflow from the undermined watered rocks into the mine workings by 3-5 times. Outside the zone of disturbance influence, an impermeable rock-bolt slab in the mine roof stops water inflow into the mine working almost completely.

Thus, the roof-bolting support can be used as a technological method for reducing the water inflow into mine workings [28, 29].

\subsection{Method of reducing fluid inflow with roof bolting}

If roof bolting is used as a technological method to reduce fluids inflows from sources located in the mine roof, additional bolts are used in the mine roof to form a powerful rock-bolt slab. Some of the additional bolts should be inclined towards the working face; the other part should be inclined in the opposite direction (Fig. 22). This contributes to a more stringent limitation of the displacement of host rocks into the mine working and preserves their natural solidity. In this case, the impermeable rockbolt slab prevents the fluids filtration into the mine working.

In fig. 22-24 the following labels are used: 1 - mine working; 2 mine face; 3 - steel-polymer bolts; 4 - steel-polymer bolts inclined at the mine face; 5 - steel-polymer bolts inclined at the mouth of mine working; 6 - gas- or water-bearing bed in the mine roof; 7 - additional wall bolts; 8 - gas- or water-bearing bed in the walls of mine working; 9 - additional bolts in the lower part of the walls; 10 - gas- or 
water-bearing bed in the floor of mine working; $a$ - distance between rows of bolts; $b$-distance between the first row of bolts and the mine face; $\alpha$ - angle of inclination of bolts to the mine face; $\beta$ - angle of inclination of bolts to the mouth of mine working.

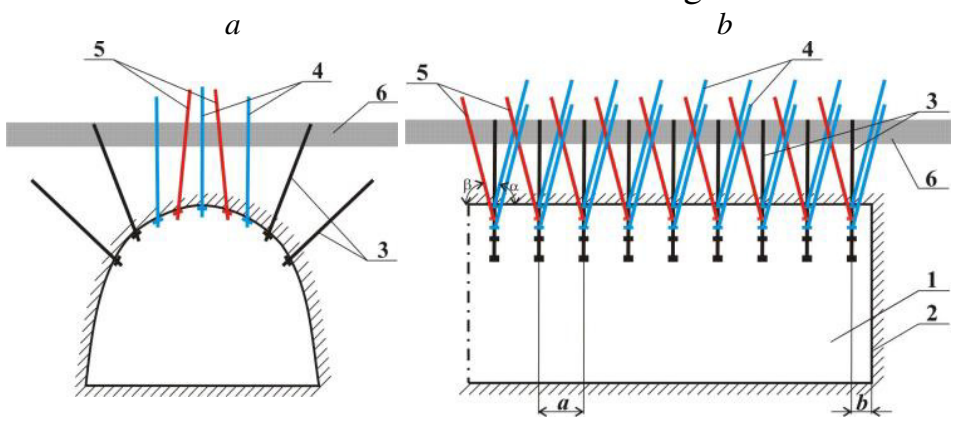

Fig. 22. The bolts location scheme in the case when fluid emission source is in the mine roof: $a$-cross-section; $b$ - longitudinal section of the mine working

If the fluid emission sources are located in the walls of the mine working, additional bolts are installed directly into the coal bed or fluid-bearing rock, Fig. 23.

$a$

$b$

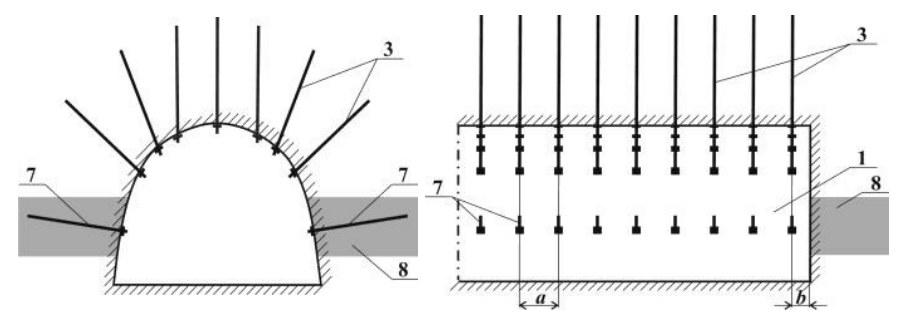

Fig. 23. The bolts location scheme in the case when fluid emission source is in the walls of mine working: $a$ - cross-section; $b$ - longitudinal section of the mine working

This prevents the onset of inelastic deformations and stratification, reduces the depth of filtration area and helps to reduce fluids inflow into the mine working.

In the case when gas- or water-bearing beds are located at the floor of working, with the help of additional bolts in the lower part of the walls of mine working and its floor, the floor heaving is limited and fluids inflow from the overworked sources is reduced. 


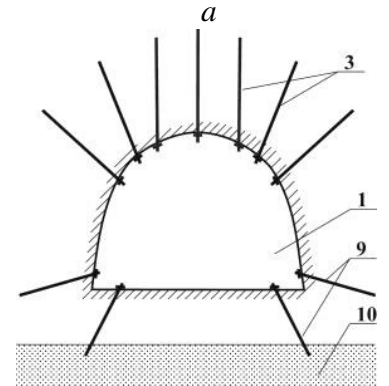

$b$

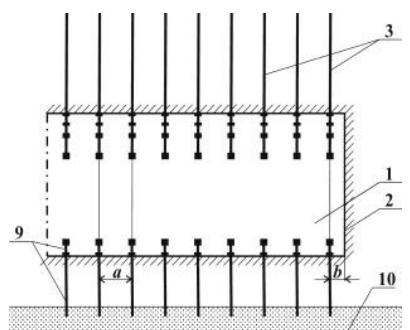

Fig. 24. The bolts location scheme in the case when fluid emission source is in the floor of mine working: $a$-cross-section; $b$ - longitudinal section of the mine working

Thus, with the help of bolts, the impermeable rock-bolt layer is created around the mine working, in which the natural solidity of the rocks is preserved. This ensures a decrease in fluids inflow into the mine working from sources in the roof, floor and walls of the mine working. Therefore, roof bolting can be used as a technological method to reduce gas emission and water inflows into mine workings [30-32], to enhance the effect of regulatory methods.

\section{Conclusions}

Roof bolting is traditionally used only to ensure the stability of mine workings and it is not considered as a means of influencing filtration processes in the host rocks. To substantiate the use of roof bolting as a technological method to reduce gas emission and water inflows into mine workings, the mathematical model of coupled processes of deformation of layered coal-rock mass and fluids filtration in the disturbed area has been developed. The cases when mine working is supported with frames and roof bolts were considered.

The investigation of influence of roof bolting on filtration permeability caused by the mine working driving has been carried out. It was shown that a filtration area with non-zero permeability coefficients is formed around the mine working with frames. Within this area, fluids can freely move in the direction from the fluids emission source into the mine working space. Roof bolting restrains the process of cracking in the zone of mine working influence. The size of filtration area is significantly reduced, the permeability inside it decreases. Roof bolting decreases the 
average filtration permeability caused by the redistribution of the stress field during excavation by 15 times or more.

The influence of roof bolting on the process of methane filtration from gas-bearing rocks and coal into the mine working has been investigated. It was shown that around the mine working with bearer frame support, the process of methane filtration is actively taking place. Methane filtration rate in the bolted area of the mine roof is equal to zero; consequently, methane from undermined gas emission sources does not participate in the filtration process. In the walls of mine working, the modulus of filtration rate in the bolted area is reduced by an average of 9 times in comparison with the mine working, which is supported by frames.

The influence of roof bolting on the process of water filtration during the undermining of water-bearing rocks has been investigated. The use of roof bolting restrains the unloading of the boundary rocks from the rock pressure and keeps them in triaxially compressed stress state. Permeability value decreases by the value of its technological component. In different areas of the intersection of tectonic disturbance, water inflow into the mine working with roof bolting is 3-8 times less than in the working with the frame supports.

Therefore, the use of roof bolting allows not only to keep the mine working in a stable state, but also to significantly reduce fluids inflows. Roof bolting can be considered as the second line of defense to be applied in the presence of gas- and water- bearing rocks. The authors have developed methods for reducing gas and water inflows using roof bolting and obtained the corresponding patents.

\section{References}

1. Bulat, A.F., \& Vinogradov, V.V. (2002). Oporno-ankernoe kreplenie gornyih vyirabotok ugolnyih shaht. Vilpo [in Russian].

2. Krukovskyi, O.P., Krukovska, V.V., Bulich, Yu.Yu., \& Zemlianaia, Yu.V. (2020). Some aspects of development and application of the bearing-bolt supporting technology. Resource-saving technologies of raw-material base development in mineral mining and processing. Universitas Publishing. https://doi.org/10.31713 $/ \mathrm{m} 901$

3. Krukovskiy, O.P., Khvorostian, V.A., \& Krukovskaia, V.V. (2013). Technology of supporting bolting of mine workings. Coal of Ukraine, 2, $13-16$ [in Russian]. 
4. SOU 10.1.05411357.010:2014. (2014). System of providing reliable and safe functioning of roof bolting mine workings. General technical requirements. Standart Ministry of Energy and Coal Mining of Ukraine [in Ukrainian].

5. Agafonov, A.V. (1998). Sposoby i sredstva obespecheniya bezopasnosti provedeniya podgotovitel'nyh vyrabotok po vybrosoopasnym plastam. Donbass [in Russian].

6. Steve Zou, D.H., Yu, Chuxin, \& Xian, Xuefu. (1999). Dynamic nature of coal permeability ahead of a longwall face. International Journal of Rock Mechanics and Mining Sciences, 36, 693-699.

7. Bai, M., Meng, F., Elsworth, D., Zaman, M., \& Roegiers, J.-C. (1997). Numerical modeling of stress-dependent permeability. International Journal of Rock Mechanics and Mining Sciences, 34:3-4, paper No. 020.

8. Krukovska, V.V. (2015). Simulation of coupled processes that occur in coalrock massif during mining operations. Geotechnical Mechanics, 121, 48-99 [in Russian].

9. Krukovskaya, V.V. (2006). Preparation method of calculation of methane filtration parameters with the account a mode of stressedly-deformed state of coalrock mass. Institute of Geotechnical Mechanics named by N.S. Polyakov NAS of Ukraine [in Russian]

10. Basniev, K., Kochina, I., \& Maksimov, V. (1993). Podzemnaya gidromehanika. Nedra [in Russian].

11. Zienkiewicz, O.C., Taylor, R.L., \& Zhu, J.Z. (2013). The Finite Element Method: Its Basis and Fundamentals, Butterworth-Heinemann.

12. de Borst, R., Crisfield, M.A., Remmers, J.J.C. \& Verhoosel, C.V. (2012). Non-linear finite element analysis of solids and structures, John Wiley \& Sons.

13. Krukovskaya, V.V. (2015). The development of the coupled processes theory in the application to geomechanics of coal-rock massif. Institute of Geotechnical Mechanics named by N.S. Polyakov NAS of Ukraine [in Russian].

14. Zhang J., \& Roegiers, J.-C. (2003). Double Porosity Finite Element Method for Borehole Modelling. International Journal of Rock Mechanics and Mining Sciences, 40, 473-483.

15. Detournay, E., \& Cheng, A. H.-D. (1993). Fundamental of poroelasticity. Comprehensive rock engineering, vol 2. Pergamon Press.

16. Chernyak, I.L., \& Yarunin, S.A. (1995). Upravlenie sostoyaniem massiva gornyh porod. Nedra [in Russian].

17. Vynohradov, V.V., Krukovskyi, O.P. \& Krukovska, V.V. (2007) Application of roof bolting constructions as technological way of the methane content decrease in the mine workings. Problems of Computational Mechanics and Strength of Structures, 11, 30-37 [in Russian].

18. Nikolin, V.I., Balinchenko, I.I., \& Simonov, A.A. (1981). Borba s vyibrosami uglya i gaza v shahtah. Nedra [in Russian].

19. Lukinov, V.V., Bezruchko, K.O., \& Prykhodchenko, O.V. (2018). Vliyanie lokal'noj skladchatosti na metanoobil'nost' gornyh vyrabotok ugol'nyh shaht. Coal of Ukraine, 1, 15-21 [in Russian].

20. Zhoglo, V.G., Grimus, S.I., \& Haletskiy, A.V. (2010). Obosnovanie modeli pronicaemosti karbonatnyh otlozhenij putem resheniya obratnyh zadach $\mathrm{s}$ 
ispol'zovaniem PK «ECLIPSE 100». Development and operation of oil and gas fields, 2, 25-30 [in Russian].

21. Bulat, A.F., Lukinov, V.V., \& Bezruchko, K.O. (2017). Umovy formuvannia hazovykh pastok u vuhlenosnykh vidkladakh. NVP «Naukova dumka» [in Ukrainian].

22. Sotskov, V.O., Zahrytsenko, A.M., \& Dereviahina, N.I. (2019). Obgruntuvannia hirnycho-heolohichnykh parametriv zastosuvannia resursozberihaiuchoi tekhnolohii selektyvnoi vidrobky vuhilnykh plastiv dlia Zakhidnoho Donbasu. Scientific notes of Taurida National V.I. Vernadsky University. Series: Technical Sciences, 6, 17-23 [in Ukrainian]. https://doi.org/10.32838/26635941/2019.6-2/04

23. Masoumi, H., Horne, J., \& Timms, W. (2017). Establishing empirical relationships for the effects of water content on the mechanical behavior of gosford sandstone. Rock Mech. \& Rock Eng., 50(8), 1-8.

24. Liu, H., Zhu, W., Yu, Y., Xu, T., Li, R., \& Liu, X. (2020). Effect of water imbibition on uniaxial compression strength of sandstone. International Journal of Rock Mechanics and Mining Sciences, 127, 104200.

25. Yang, T., Zhu, W., Yu, Q., \& Liu, H. (2011). The role of pore pressure during hydraulic fracturing and implications for groundwater outbursts in mining and tunnelling. Hydrogeol. J., 19(5), 995-1008.

26. Li, L., Yang, T., Liang, Z., Zhu, W., \& Tang, C. (2011). Numerical investigation of groundwater outbursts near faults in underground coal mines. Int. J. Coal Geol., 85(3-4), 276-288.

27. Vinogradov, V.V. (1989). Geomechanics of massif condition control near mining. Naukjva Dumka [in Russian].

28. Vynohradov, Yu.O. (2015). Analysis of the water inflow in mine working depending on the support type. Modern resource-saving technologies of mining production, 1, 89-95 [in Russian].

29. Krukovska, V. \& Vynohradov, Y. (2019). Water stability influence of host rocks on the process of water filtration into mine working with frame and roofbolting support. Essays of Mining Science and Practice 2019. E3S Web of Conferences, 109, 00041 https://doi.org/10.1051/e3sconf/201910900041

30. Vynohradov, Yu.O. (2018) Development of a method for reducing water inflow and increasing the stability of mine workings in difficult hydrogeological conditions. Institute for Physics of mining processes of NAS of Ukraine [in Ukrainian].

31. Krukovskyi, O.P., Krukovska, V.V., \& Vynohradov, Yu.O. (2016) Sposib znyzhennia vodopryplyvu u hirnychu vyrobku iz zastosuvanniam ankernoho kriplennia. Inventions (utility models) in Ukraine, 111059 [in Ukrainian]. https://base.uipv.org/searchINV/search.php?action=viewdetails\&IdClaim=228741\& chapter=description

32. Krukovska, V.V., \& Krukovskyi, O.P. (2018). Sposib znyzhennia metanovosti hirnychykh vyrobok iz zastosuvanniam ankernoho kriplennia. Inventions (utility models) in Ukraine, 124356 [in Ukrainian]. https://base.uipv.org/searchINV/search.php?action=viewdetails\&IdClaim=245815\& chapter $=$ description 